腸重積を呈した回腸悪性リンパ腫の 1 例

\begin{tabular}{llllll}
\multicolumn{9}{c}{ 安城更生病院外科 } \\
沈 & 秀明 & 鈴木 & 正康 新実 & 紀二 \\
亀岡 & 伸樹 & 平岩 & 克正 & 山田 & 満昭
\end{tabular}

\title{
A CASE REPORT OF MALIGNANT LYMPHOMA OF THE ILEUM WITH INTUSSUSCEPTION
}

Hideaki CHIN, Masayasu SUZUKI, Noriji NIINOMI, Nobuki KAMEOKA, Katsumasa HIRAIWA and Mitsuaki YAMADA

Department of Surgery, Anjō Kōsei Hospital

索引用語：成人腸重積症, 回腸悪性リンパ腫

はじめに

成人腸重積症は全腸重積症の 5 〜 10\%を占めると言 われ(1)，乳幼児に比べ器質的疾患が原因となる場合が 多い，著者らは回腸悪性リンパ腫が原因となった回盲 部腸重積症を経験したので若干の文献的考察を加党報 告する。

\section{症 例}

症例：38歳, 男性.

主訴: 間歇的腹痛.

既往歴・家族歴：特記すべきことなし。

現病歴: 昭和 58 年 1 月 10 日頃より間歇的腹痛が出現 した，近医受診し胃透視受けるも異常はなかった。 2 月 2 日本院受診し, 注腸にて回盲部に陰影欠損がみら れた. 2 月 15 日精査・加療のため入院した.

入院時現症: 両腋窩・両単径部にリンパ節を触知し た. 腹部はやや膨隆し, やや硬く, 腸音は元進してい た. 右上腹部・右下腹部に圧痛が存在した。腫瘤は触 知しなかった。

入院時倹査成績: 心電図が洞性徐脈以外血液生化 学, 腎機能, 肺機能などに異常はなかった。

腹部単純 $\mathrm{X}$ 線写真：立位像であるが, 回盲部にガス 像がみられ，小腸ガス像も存在した（図 1).

注腸：回盲部に陰影欠損がみられ, 蟹爪像も存在し た(図2).

上腸間膜動脈造影：回結腸動脈, 右結腸動脈が上方 一偏位し, hairpin curve sign, 腸間膜血管との直角交

$<1988$ 年 6 月 8 日受理 >別刷請求先 : 沈 秀明

T112 文京区目白台 $3-28-6$ 東京大学医学部第 3 外科
図 1 腹部単純 $\mathrm{X}$ 線写真：回盲部にガス像がみられ, 小腸ガス像も存在した。

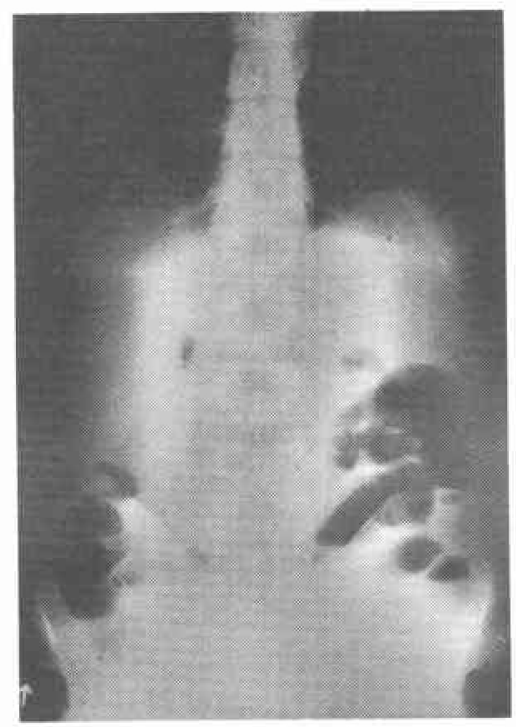

叉がみられた, retrospectiveにみると矢印の部に淡い tumor stain, 軽度の動脈の狭窄がみられた（図 3）。

患者は入院後も間歇的腹痛を訴兄, 覀心・呕吐を繰 り返した。質的診断は下しえなかったが，回盲部腸重 積症と診断，2月25日手術を施行した。

手術所見: 下腹部正中切開にて開腹, 腹水・肝転移・ 腹膜播種はなかった，虫垂は通常の位置にあり，回盲 部に手拳大の腫瘤が存在, 回腸は盲腸・上行結腸に嵌 入し，回腸結腸型腸重積症がみられた（図 4 )。整復を 試みるも成功せず，悪性腫場を考虑しリンパ節郭清を 
図 2 注腸：回盲部に陰影欠損がみられ，蟹爪像も存 在する.

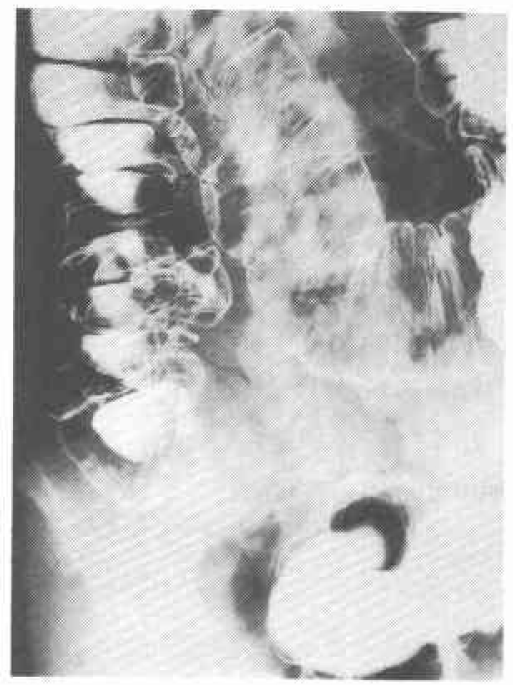

因 3 上腸間膜動脈造影 : hairpin curve sign がみら れる. 矢印の部に淡い tumor stain, 動脈の狭窄がみ られる。

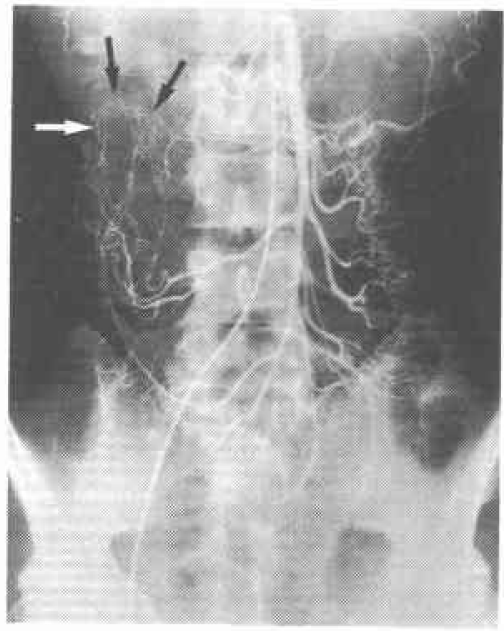

含む右半結腸切除術 $\left(\mathrm{R}_{3}\right)$ を行った。

摘出標本：回盲弁上り $2.0 \mathrm{~cm}$ 口側の回腸末端に $6.0 \times 4.5 \times 3.0 \mathrm{~cm}$ のポリープ状腫湟が存在した（図 $4)$.

組織標本：腫瘍は diffuse, large cell type の malignant lymphoma (B cell type, immunoblastic type) で, 浸潤は固有筋層を越克漿膜下に及んでいた。 lymphoma cells は大型円形核, 両染性のやや広い胞体 を持ち, I ～3 個の明瞭な核小体を備えていた(図 5).
図 4 手術所見. 摘出標本：回腸末端は盲腸，上行結 腸に茨入し（上），回盲弁上り $2.0 \mathrm{~cm}$ 口側に $6.0 \times$ $4.5 \times 3.0 \mathrm{~cm}$ の腫焬が存在した（下）.
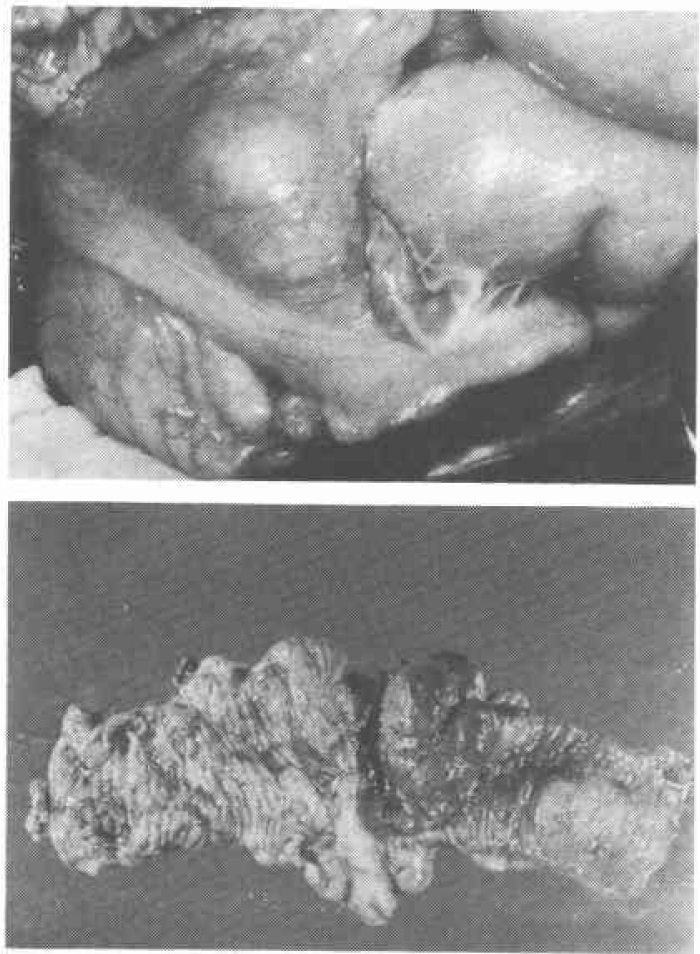

リンパ節転移は 1 個（No. 201，1/14）みられた。

術後経過：単径部リンパ節生検, リンパ管造影で異 常はなかった。回腸末端原発悪性リンパ腫(stage IIE) と診断，1年間 VEP 療法を行らことにし 4 月18日退 院した。昭和59年 8 月 second look operation 施行, 再発を認めなかった。昭和59年 9 月27日より CPOB 療 法を 3 回施行した. CT, ェコー, 注腸にて再発は認め ていない。

\section{考察}

成人腸重積症の全腸重積症に占める割合は 5〜10\% と比較的少ない:

乳幼児の場合と異なり, 成人腸重積症は 2 次性が

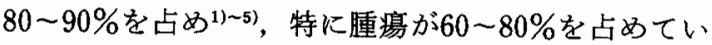

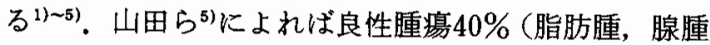
が多く, 小腸特に回腸に多い), 悪性腫瘍38.3\%(45.9\% は癌腫で大腸に多い，40\%は悪性リンパ腫で回腸に多 い, その他非特異的炎症, Meckel 喤室, 迷入膵, リ ソパ汇胞増殖症などの非腫瘍性病変が $10.9 \%$ 占めて いる. 
図 5 組織標本：浸潤は固有筋層を越え漿膜下に及ん でいた(上，ルーペ像). diffuse, large cell typeの malignant lymphoma の像である(下, $\mathrm{HE} \times 200)$.
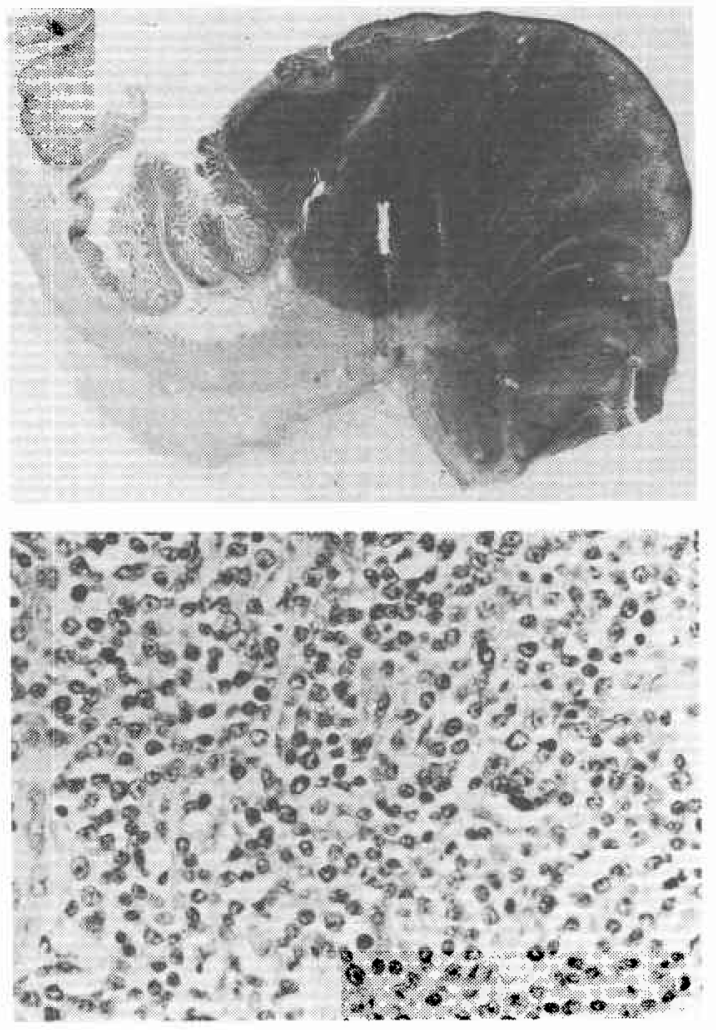

病悩期間は比較的長く, 1 力月から 1 年にわたり, 1 カ月前後が多〈6)7, , 間歇的腹痛, 悪心・呕吐なぞの 閉塞症状が慢性的経過をとる場合が多い?.

成人腸重積症の分類別頻度では回腸回腸型 $26.2 \%$, 回腸結腸型 $23.0 \%$, 回腸盲腸型 $19.3 \%$ の順となり ${ }^{5)}$, 回 盲部を中心として多発している。

小腸悪性リンパ腫の15.6\%は腸重積症を呈して発見 される8). 頻度的にも回腸は空腸の約2.6倍悪性リンハ 腫が多く ${ }^{8)}$, 回腸覀性リンパ腫の25～50\%は腸重積症 の原因となっている゙．鈴木ら7は小腸覀性リンパ腫に よる成人腸重積症 20 例の 5ち18例が回腸末端に位置し ていたとしている．回盲部癌が腸重積を起こした例も 報告されてはいるが10), 回盲部腸重積症の場合覀性腫 湯としてまず第 1 に回腸末端悪性リンパ腫が想起され ねばならない。

注腸等の X 線造影検査以外に, 血管造影検査が腸重 積症の診断, 特にその部位・質的診断に役立つとする 報告がみられる ${ }^{10) ~ 13)}$. hairpin curve sign, 腸間膜血
管との直角交叉などが腸重積症の診断根拠にあげられ ている。悪性リンパ腫の血管造影の特徴的所見として hypovascularないし淡い tumor stain，血管の王排・ 偏位, 中等度の病的血管の増生, 比較的長い範囲にわ たる狭窄などがあるが1014)，必ずしも癌との鑑别は容 易ではない.しかし良性腫瘍との鑑別は容易となろう。 自験例では術前に回盲部腸重積症の診断は下乙えた が，質的診断は出来なかった.しかし retrospectiveに みると軽度の血管の狭窄, 淡いtumor stain が先進部 に認められ，癌との鑑別は困難であるが，木ず悪性リ ンパ腫が想起されねばならなかった。

成人腸重積症の治療としては, その原因疾患として 器質的疾患が多いことから, 観血的治療法が選択され るのが一般的である ${ }^{2) 3}$. 悪性腫瘍の頻度が高い事を考 慮し，整復を試みずただちに腸切除を行うとする意見 もある . 逆にまず整復を試み，その後腸切除を考虑す べきとする意見もある ${ }^{2)}$. 本症の $20 \%$ 前後は器質的疾 患を欠き，良性腫瘍むその原因となることが多いこと から 5)11，ま才整復を試み原因疾患を追求し，しかるの ら腸切除を考慮するのが妥当と思われる。

\section{おわりに}

回腸悪性リンパ腫が原因となった回腸結腸型腸重積 症を経験したので若干の文献的考察を加光報告した。

本症例の要旨は第207回東海外科学会（昭和58年11月20 日）において発表した。

東京大学第 3 外科大原 毅教授の御校閲に深謝致しま 于.

\section{文献}

1) Brayton $\mathrm{D}$, Norris $\mathrm{WJ}$ : Intussusception in adults. Am J Surg 88:32-43, 1954

2) Dean DL, Ellis FH, Sauer WG : Intussusception in adults. Arch Surg 73:6-11, 1956

3) Sanders GB, Hagan WH, Kinnaird DW : Adult intussusception and carcinoma of the colon. Ann Surg 147：796-804, 1958

4）堀 公行: 成人腸重積症一 6 治験例と本邦最近 10 年間の報告症例の集計をるととして一. 外科 38 : 692-698, 1976

5）山田修司，笹野伸昭，氏家紀一ほか：回腸リンパ沪 胞増殖症を伴った成人回盲部腸重積症の 1 例. 外 科 $44: 215-219,1982$

6）小島靖彦, 中川原儀三, 泉 良平はか：術前に診断 しえた小腸腫瘍による成人腸重積症の経験. 外科 $43: 1376$ - 1378, 1981

7）鈴木㖵一, 斎藤正光,佐久間仁ほか：小腸原発性悪 性リンパ腫による成人腸重積症の 1 例. 消外 $10: 907-912,1987$ 
8）八尾佰良, 日吉雄一, 田中啓二ほか：最近10年間 （1970-1979）の本邦報告例の集計からみた空・回 腸腫湯一I. 悪性腫癔. 胃と晹 $16: 935-941,1981$

9）桧山 護：俓性回盲部腸重積を来した回腸末端原 発悪性リンパ腫の 1 例. 胃と腸 $8: 227-231$, 1973

10）小林一雄, 森 克彦, 永沢康滋注か：小腸疾患にお ける血管造影の経検。日消外会誌 $16: 576-582$, 1983

11）化尾義則, 市川利洋, 新田直樹ほか：回腸脂肪腫に
起因する騰重積症の 1 例. 冒と腸 $17: 806-810$, 1982

12) Chang TT, Huang TY: Arteriographic diagnosis of intussusception-three case reports. Am J Radiol 117 : 317-322, 1973

13）沢田 敏, 播磨敬三, 深谷徳幸ほか：成人腾重程症 の X 線検査一各種の造影検查を中心として一. 綜 合臨 $28: 199-205,1979$

14）度辺俊一，大㚼武夫，伊津野格：覀性リンパ重の娌 破造影所見。日医放線会誌 $36 ： 316-321,1976$ 